\title{
GA-A15514
}

\section{STEAM INGRESS REACTIVITY EFFECTS IN THE GCFR}

by

\author{
A. L. HESS and C. J. HAMILTON
}

JULY 1979

\section{GENERAL ATOMIC COMPANY}




\section{DISCLAIMER}

This report was prepared as an account of work sponsored by an agency of the United States Government. Neither the United States Government nor any agency Thereof, nor any of their employees, makes any warranty, express or implied, or assumes any legal liability or responsibility for the accuracy, completeness, or usefulness of any information, apparatus, product, or process disclosed, or represents that its use would not infringe privately owned rights. Reference herein to any specific commercial product, process, or service by trade name, trademark, manufacturer, or otherwise does not necessarily constitute or imply its endorsement, recommendation, or favoring by the United States Government or any agency thereof. The views and opinions of authors expressed herein do not necessarily state or reflect those of the United States Government or any agency thereof. 


\section{DISCLAIMER}

Portions of this document may be illegible in electronic image products. Images are produced from the best available original document. 
This report was prepared as an account of work sponsored by the United States Government. Neither the United States nor the Department of Energy, nor any of their employees, nor any of their contractors, subcontractors, or their employees, makes any warranty, express or implied, or assumes any legal liability or responsibility for the accuracy, completeness or usefulness of any information, apparatus, product or process disclosed, or represents that its use would not infringe privately owned rights. 
GA-A15514

\section{STEAM INGRESS REACTIVITY EFFECTS IN THE GCFR}

by

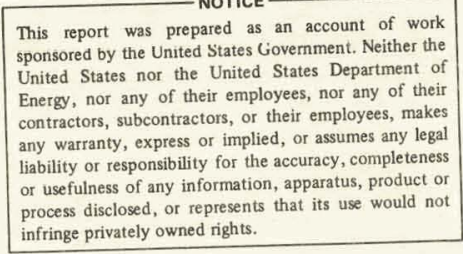

A. L. HESS and C. J. HAMILTON

This is a preprint of a paper presented at the Helium Breeder Associates/Department of Energy GCFR Program Technical Review Meeting, May 31, 1979, Rancho Bernardo, California, and to be published in the Proceedings.

Work supported by

Department of Energy

Contract DE-AT03-76SF71023

GENERAL ATOMIC PROJECT 6113

JULY 1979

\section{GENERAL ATOMIC COMPANY}




\title{
STEAM INGRESS REACTIVITY EFFECTS IN THE GCFR*
}

\author{
A. L. Hess and C. J. Hamilton \\ General Atomic Company \\ San Diego, California
}

\section{INTRODUCTION}

Because of the higher pressure on the steam side of the steam generator in the gas-cooled fast breeder reactor (GCFR), the potential exists for steam-generator tube leaks or ruptures which might introduce water vapor into the primary coolant and thence into the core region. This potential for core steam ingress requires that a satisfactory understanding of the reactivity effects due to various concentrations of hydrogeneous material in the core be achieved.

The reactivity effects resulting from an increase in hydrogen density are two-fold: a decrease in neutron leakage from the core, and a moderation of the neutron energy spectrum. The leakage effect is always positive and is predominant in smaller systems with attendant higher leakage fractions. The sign and the magnitude of the spectrum effect are highly dependent on core design variables, including coolant volume fraction, fuel fissile enrichment, and plutonium isotopic makeup, and on the degree of neutron poisoning, either by inserted control rods, fission product accumulation, or deliberate admixtures in the fuel of low-energy absorbers. Also, the cold-to-hot operating core temperature transition produces a negative reactivity effect (to a large extent due to the Doppler effect on absorption in $\mathrm{U}-238$ ), which is substantially increased by progressive softening of the spectrum due to hydrogen addition. Hence, the magnitude and even the sign of the net resultant reactivity change depends on a subtle balance between contributing terms, and its accurate prediction is thus a stringent test of calculational methods and basic cross section data.

*Work supported by the Department of Energy, Contract DE-AT03-76SF71023. 
This paper reviews the past quantifications of the impact of steam ingress on GCFR safety, outlines the current status of methods employed for steam-worth analysis, and demonstrates that these methods give good agreement with measurements conducted in the initial GCFR critical-experiment program. It will be shown that the experiments already conducted provide upper reactivity limits for anticipated effects from achievable steam densities. Quantification of this limit eliminates steam ingress from the list of significant safety concerns. Analytical results for other core-physics parameters are also presented to show how the general validation program of core design physics methods and data for the GCFR has been initiated.

\section{HISTORICAL REVIEW}

The potential effects from accidental core steam ingress have been considered in the design analyses for the GCFR concept from the very beginning. In the initial design studies (Refs. 1, 2), calculated wateringress effects were reported for up to $100 \%$ water density of the coolant channels of a 5000-1iter core design. These studies indicated slightly negative water-ingress worth below $10 \%$ channel water density in a hot, fresh loaded core without added poisons or rods, but which becomes positive above 10\%. Concentrations for admixed neutron poisons, such as gadolinium, were studied to assure negative effects for all densities and allow for total flooding. Other studies (Ref. 3) at the time considered the prospects for flooding reactivity control in steam- and helium-cooled fast reactors using a variety of neutron poisons.

In a 1966 General Atomic (GA) design study (Ref. 4) for a 1000-MW(e) GCFR, the concept of admixed poisons was noted to introduce problems in fuel development, to decrease breeding ratio, and to lower coolant volume. Hence, a solution based on limiting total water accessible to the primary coolant was deemed desirable. An upper 1 imit of about $8 \%$ steam in the coolant, from the steam generators, would limit the reactivity effect to less than $+\$ 1$ for a hot unpoisoned core. In further physics and safety 
analyses (Ref. 5) for this 1000-MW(e) design, detailed investigations of analytical methods were carried out, showing that more exacting treatments are required for evaluating steam effects than are required for normal design calculations. In particular, the neutron cross section group averaging must account for the gross spectrum differences at different steam densities, and spatial flux changes need to be considered for twodimensional reactor calculations. The prospects for emergency cooling by flooding with highly poisoned water were also examined.

In the foregoing preliminary design studies, the concept of batch reloading (which took advantage of internal core breeding ratios near unity) was assumed. This provided for startup and cycle-length operations with little control rod poisoning. In part, this unpoisoned situation contributed to the positive steam worth evaluations then obtained. Subsequent improvements in the accuracy of evaluated nuclear data provided higher capture of fission $(\alpha)$ ratios for plutonium. This resulted in lower breeding ratios for fast reactors and a higher burnup worth over the GCFR fuel cycle, thus requiring start-of-cycle rod insertions. The presence of control rods and/or the accumulation of fission product poisoning in any real GCFR configuration, coupled with the higher plutonium and uranium absorption cross sections at lower energies, then provided new steam-ingress reactivity predictions which were negative for realistic coolant steam contents. Pellaud (Ref.6) reports on the status of these GCFR physics methods as of 1971 and shows the negative worth for up to $6 \%$ steam for start and end of cycle configurations of the 300-MW(e) GCFR.

A specific study on the steam-entry effect for a demonstration plant was reported by Broido and Rothstein in 1972 (Ref. 7). In this work, steam worth for clean rodded and burned unrodded configurations was evaluated in perspective to the potential steam densities resulting from maximum leak of a steam generator with and without dump; for the total inventory of three generators; and for an absolute maximum of $5 \%$ steam hypothesized for $100 \%$ saturation at hot temperatures and $90 \mathrm{~atm}$ pressure. The graphs of their calculated results, based on ENDF/B Version-3 nuclear data, are given in Fig. 1. 
Additional information pertaining to steam worth in fast reactors is provided by the several past investigations, theoretical and experimental, on behalf of design efforts for steam-cooled breeder reactors, particularly from studies of the steam voiding effect. Here, however, much larger channel steam densities were involved, upwards to $0.12 \mathrm{~g} / \mathrm{cm}^{3}$ for normal operations, and to $100 \%$ water for emergency cooling. Theoretical studies (Refs. 9-11) for various steam-cooled designs gave somewhat conflicting assessments of reactivity variation with channel steam density. Part of the conflict stems from different basic design assumptions, but also methods for cross section preparation and reactor modeling in some cases were not of comparable rigor as for the others. Some important aspects revealed in these studies, however, are the marked sensitivity exhibited for the steam worth at densities beyond $10 \%$ to the degree of fuel burnup and to the isotopic fraction of Pu-240 in plutonium. For example, for $0.2 \mathrm{~g} / \mathrm{cm}^{3}$ channel steam, fuel of unburned pure $\mathrm{Pu}-239$ (plus $\mathrm{U}-238$ ) was worth $+2 \% \Delta \mathrm{k}$ (relative to void), while for $22 \% \mathrm{Pu}-240$ at $40 \mathrm{MWd} / \mathrm{kg}$ burnup, the effect was calculated at $-5 \% \Delta \mathrm{k}$.

Experimental studies in Germany (Ref. 12) and Sweden (Ref. 13) for the steam-cooled fast reactor concepts also provided some early tests of methods appropriate to steam worth analysis. The SNEAK critical assembly experiments for a 670-liter design utilized polyethylene to simulate core average steam at about $0.01 \mathrm{~g} / \mathrm{cm}^{3}$, or about $0.032 \mathrm{~g} \mathrm{H}_{2} \mathrm{O} / \mathrm{cm}^{3}$ in a coolant volume fraction of $35 \%$. Step-wise removal of the $\mathrm{CH}_{2}$ (mocking up a coolant-voiding accident) provided a measured total-core effect of $-\$ 4.2$, or a $+\$ 4.2$ worth of the hydrogenous material relative to void. Measurements in the FRO (Ref. 13) coupled fast/thermal reactor with a central GCFR-like lattice likewise indicated positive worths for $\mathrm{CH}_{2}$ replacing void at volume fractions ranging between 0.018 and 0.075 , again in a cold-temperature reactor situation. The more significant experiment in this FRO study, however, was the measurement of the U-238 Doppler coefficient for a small sample situated at core center with and without the simulated steam flooding. The steam flooding was found to triple the negative reactivity effect measured during the sample heatup. 
Reports on central-worth measurements in the numerous fast reactor criticals, with enriched $\mathrm{U}$ and plutonium fuel, with and without sodium, etc., have in several instances cited results for small samples of polyethylene. In all cases, the $\mathrm{CH}_{2}$ worth was measured positive, and strong sample size effects were noted (Ref. 14). However, as for the above-cited experiments in steam-cooled fast critical representations, the samples in all cases were in a cold, unpoisoned core environment.

STEAM WORTH STUDIES IN GCFR CRITICAL EXPERIMENTS

The development program for the 300-MW(e) GCFR demonstration plant project includes progressive stages of critical experiments (Ref. 15) with GCFR-simulated configurations to study physics characteristics and to validate core design methodologies. The first stage, completed in 1976, was a three-phase series of clean-geometry assemblies on the ZPR-9 facility at Argonne National Laboratory (ANL). Steam-worth studies formed an. important segment of the experiments conducted in all three assembly phases. The following sections review briefly the basic details of these three assemblies and the steam ingress experiments thereon, describe the analytical methods used, and compare the results of calculations with the measurements.

The Phase I assembly, described in detail by Bhattacharyya (Ref. 16), was a simple-geometry GCFR mockup configuration, i.e., with a single zone 3150 liter core, uniform radial and axial blankete, and no rod channels or structural gaps. The steam-worth experiments in this assembly were limited to a central 47-liter core zone as a scoping study for testing methods and for planning experiments in later phases. The Phase I system closely represented the demonstration plant design in core size, void fraction, and average fuel makeup. However, distinctions between this aзsembly and the power reactor environment to be recognized include:

1. The plate-versus-rod structure of the fuel, giving stronger heterogeneity effects. 
2. The larger individual void channels, with greater neutron streaming characteristics.

3. The lack of control-rod or fission-product poisoning.

4. The low-temperature, zero-power operation of the critical facility.

All four of these factors have appreciable influence on the worth of steam ingress. To predict the worth of steam in the complex power reactor situation, however, the ability to properly interpret the experiments in the simple, clean-geometry GCFR mockups must be demonstrated. The purpose of the studies in Phase I was to provide a starting point for understanding steam-worth effects.

The Phase II assembly (Ref. 17) was a reduced-size version of Phase I, with a 1300-1iter core achieved by reducing the volume fraction of the coolant channels from $55 \%$ to $44 \%$. The major purpose of this size reduction was to allow full reactor steam flooding experiments with available materials. Objectives of the steam-entry studies, using polyethylene foam to simulate steam at about $0.035 \mathrm{~g} / \mathrm{cm}^{3}$ maximum, included:

1. Measuring steam worth versus density for different geometric configurations.

2. Determining the influence of control rod poisoning on steam effects.

3. Evaluating the control rod worths in the presence of steam.

4. Studying flooding effects on other physics parameters.

The Phase III assembly core was similar in size to that of Phase II, only with three fuel enrichment zones as a simulation of the core zoning required in the power reactor to achieve power flattening. Steam ingress 
studies in Phase III were limited to central region experiments in correlated pin-type and plate-type fuel environments.

The study of steam effects in these critical assemblies was carried out through insertion of the $\mathrm{CH}_{2}$ foam slabs into the voided steel boxes used to simulate coolant channels. The resulting plate-type material arrangements required extra precautions in the generation of cross sections to account for cell-heterogeneity effects, which are appreciably greater than effects encountered in the power reactor core environment. Starting point for the cross section generation was the nuclear data on the Evaluated Nuclear Data F1le-B (ENDF/B) tapes, Versinn-4. The GA processing codes for the ENDF/B data prepare inputs for the neutron spectrum-group averaging code GGC5. For the steam studies, several runs of the GGC5 code were utilized, one for each specific core or blanket cell involved and with each of the different average densities of the $\mathrm{CH}_{2}$ insertion into the coolant channels. Following from these were specific cell problems with the one-dimensional transport code DTFX to prepare cell-heterogeneity correction factors for the GGC5 output cross sections. Also, neutronstreaming effects were accounted for by utilizing bidirectional adjustment factors for diffusion coefficients in the diffusion calculations; here too, the variations in factors with steam density were effected. The neutronic calculations for the determination of configuration reactivities were carried out with the two-dimensional diffusion theory code 2DB. Figure 2 diagrams the general course of the calculations for each steam density.

Results of the steam-ingress simulation in the central zone of the 3100-1iter Phase I core are shown in Fig. 3 (the points labeled "ANL measurements"). It is observed that the steam worth here is positive, in accord with the previously cited results in other clean-core, cold critical experiments. Also, shuwi on the figure are the results of $\mathrm{GA}$ calculations utilizing various degrees of rigor; the lower curves point out the serious errors which can result from the more approximate treatments for cross section preparation and experiment modeling. The complete details on this analysis wore reported by Hess (Ref. 18). 
Figure 4 outlines the midplane configuration for the Phase II GCFR assembly wherein full core and blanket substitutions of $\mathrm{CH}_{2}$ for void were carried out. The reactivity effects measured for the stepwise $\mathrm{CH}_{2}$ substitutions are shown as the points labeled "ANL measurements" on Fig. 5 for the unrodded assembly experiments and on Fig. 6 for the experiments w1th efght simulated GCFR control rods installed in the core. The curves on these two figures are the results of the GA calculations utilizing extensively rigorous treatments, especially the re-averaging of cross sections for the differently moderated environments. It is seen here that the energy-grnup structure for cross sections can influence results appreciably.

Comparison of Figs. 5 and 6 analytical results shows that the steam worth can be predicted equally well with and without control poison insertion; this, however, can only result from detailed reevaluation, as was done, for the rod self-shielding effects in each of the different steam environments. The comparison of the two sets of experimental data also shows the significant negative impact of the rod poisoning on the steam reactivity effect, verifying the qualitative predictions of past analyses. The agreement of the 28-group calculations with experiments is remarkably good, considering that the overall uncertainty (due to errors in nuclear data base, method and model approximations, etc.) is probably on the order of the 10-group to 28-group spread in calculated results. The full analysis for these Phase II experiments is reported by Hess, et al. (Ref. 19).

METHODS VALIDATION STUDIES

The program of measurements on the GCFR benchmark critical assemblies provided a wealth of data by which methods for the GCFR physics design can be validated. The accuracy in prediction of a wide variety of core characteristics impacts heavily on tolerance for plant core design, safety assessments, and fuel-cycle economic evaluations. A number of experimental/ calculational comparisons are given below for parameters measured in the initial GCFR critical assemblies as an indication of the current status of the physics-related GLFk design merhods. 
Table 1 lists measured and calculated reactivity parameters for several of the as-built critical configurations studied in the benchmark program. The overall calculated-to-experimental (C/E) ratios for the eigenvalues show a bias of about $-0.7 \%$, which is essentially identical to the bias obtained by LMFBR analytical groups for calculations on the 350-MW(e) sodium fast critical assemblies.

TABLE 1

SUMMARY OF GA ANALYSES OF GCFR BENCHMARK CRITICAL EXPERIMEN'SS USING ENDF/B-4 CROSS SECTIONS

\begin{tabular}{|c|c|c|c|c|}
\hline \multirow[b]{2}{*}{ GCFR Assembly } & \multirow{2}{*}{$\begin{array}{l}\text { Core Void } \\
\text { Fraction } \\
(\%)\end{array}$} & \multirow{2}{*}{$\begin{array}{l}\text { Core Volume } \\
\text { (liters) }\end{array}$} & \multicolumn{2}{|c|}{$\begin{array}{c}\text { Reactivity of } \\
\text { Reference Configuration }\end{array}$} \\
\hline & & & Measured & Calculated $(a)$ \\
\hline Phase I & 55 & 3148 & 1.0008 & 1.0032 \\
\hline $\begin{array}{l}\text { Phase II } \\
\text { without reflector }\end{array}$ & 44 & 1308 & 1.0012 & 0.9921 \\
\hline $\begin{array}{l}\text { Phase II } \\
\text { with reflector, (b) dry }\end{array}$ & 44 & 1241 & 1.0007 & 0.9920 \\
\hline $\begin{array}{l}\text { Phase II } \\
\text { with reflector } \\
\text { simulated steam } \\
\text { flooding }\end{array}$ & $\begin{array}{l}44 \\
(\text { with } 17.5 \\
\left.\text { g/1 } \mathrm{CH}_{2}\right)\end{array}$ & 1213 & 1.0014 & 0.9938 \\
\hline $\begin{array}{l}\text { Phase III } \\
\text { 3-zone core }\end{array}$ & 44 & 1911 & 1.0022 & $\sim 0.991$ \\
\hline
\end{tabular}

(a) 10-group diffusion-theory calculations, RZ-geometry, including streaming effects.

(b) Approximately 15 -cm-thick steel regions added beyond $\mathrm{UO}_{2}$ radial and axial blankets.

Measured worths of control rods inserted into the Phase II benchmark core are compared with calculations in Table 2. The experiments included single rod insertions at core center, and a pattern of a center rod plus seven rods in a mid-core ring with a total control value of about $\$ 6$ reactivity, similar to what could be expected for the start-of-cycle rod 
TABLE 2

ANALYSIS OF MOCKUP CONTROL ROD WORTHS IN PHASE II GCFR ASSEMBLY WITH AND WITHOUT SIMULATED STEAM INGRESS

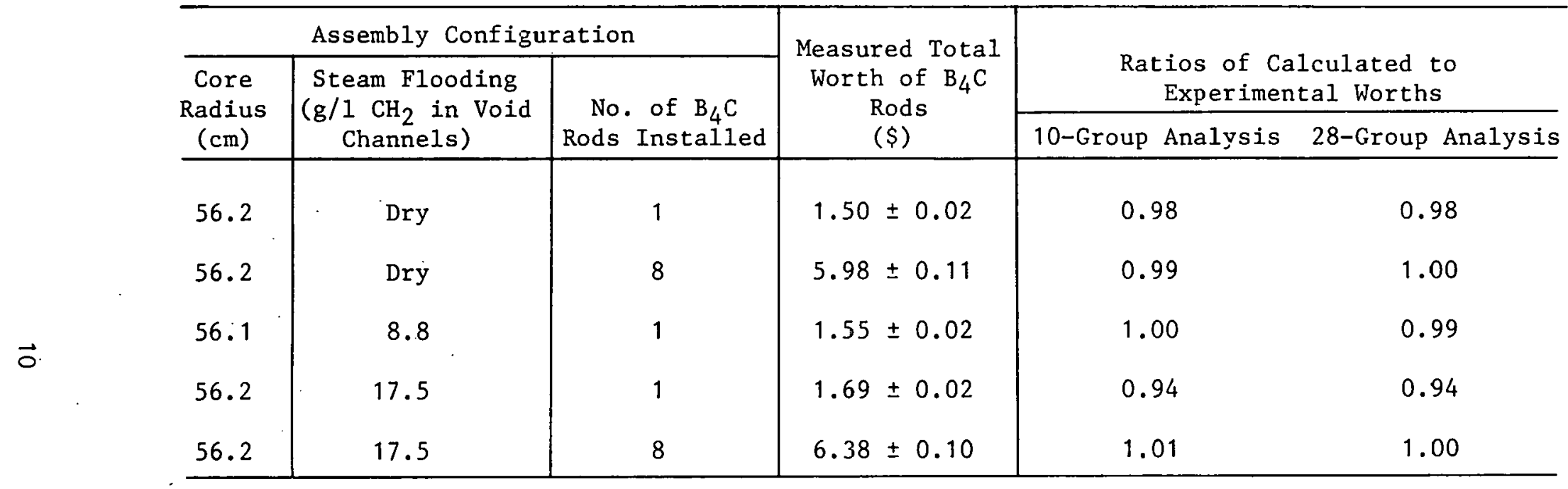


insertion for a 300-MW(e) GCFR. The experiments were done with and without simulated steam flooding, and it is seen that the calculation with appropriately reevaluated rod-shielding corrections gives equally acceptable agreement with measurements.

The relevance of the steam-worth experiments in the cold critical assemblies to the predictions of steam-ingress effect in an actual power reactor would not be established without a validation for the treatment of temperature effects with and without steam. For this reason, Doppler effect experiments were carried out in the Phase II assembly, with and without $\mathrm{CH}_{2}$ addition, for a small sample of uranfum oxide at the core center. The sample was heated over a range from $300 \mathrm{~K}$ to $1100 \mathrm{~K}$, and the associated reactivity change measured. Table 3 gives analytical/experimental comparisons for the observed temperature coefficient of reactivity in the different media. It is seen that the methods used are well able to account for the temperature and steam-flooding effect. The experiments and analysis confirm the strong negative impact of temperature on steam worth which has been predicted from the very first considerations in GCFR design.

The power distributions in the critical assemblies are measured via activation of uranium and plutonium foils emplaced throughout the core and blanket. Although at essentially zero power, the reaction profiles obtained are almost the same as if the power were at $300 \mathrm{MW}(\mathrm{e})$. The power plant distribution predictions thus are validated by the critical measurements. Figure 7 illustrates fission and capture rate distributions measured in the Phase III GCFR assembly in comparison with calculated curves. With normalizations at the core center, it is seen that the fission profile for $\mathrm{U}-238$ is we11 predicted but that the calculated U-235 fission and U-238 capture rates are increasingly underpredicted in the outer core blanket regions. Such discrepancies are not unlike corresponding comparisons for LMFBR assemblies. 
TABLE 3

COMPARISON OF MEASURED DOPPLER WORTHS IN PHASE II GCFR CRITICAL ASSEMBLY WITH GA CALCULATIONS

\begin{tabular}{l|c|c|c}
\hline & $\begin{array}{c}\text { 10-Group Calculation } \\
\text { for Dry Phase II }\end{array}$ & $\begin{array}{c}28-G r o u p \text { Calculation } \\
\text { for Dry Phase II }\end{array}$ & $\begin{array}{c}\text { 28-Group Calculation } \\
\text { for Wet Phase II }\end{array}$ \\
\hline $\begin{array}{l}\text { Contributions to zalculated Doppler } \\
\text { Dorth (ih/kg U-233) }\end{array}$ & & \\
UO ${ }_{2}$ sample. & -0.545 & -0.571 & -1.197 \\
Sample-capsule resonance interaction & -0.0014 & -0.0010 & -0.0017 \\
Sample-core resonance interaction & -0.0446 & -0.0272 & -0.0329 \\
Total calculated Doppler worth (ih/kg) & -0.591 & -0.599 & -1.232 \\
Experimental Dopfler worth (ih/kg) & -0.623 & -0.623 & -1.197 \\
Calculated-to-exFerimental ratio & 0.949 & 0.962 & 1.029 \\
\hline
\end{tabular}


FUTURE EXPERIMENTS AND DEVELOPMENTS

Because of time limitations in the benchmark series of GCFR assemblies, some important steam-worth studies were carried over for inclusion in the program for the next series of GCFR critical assemblies, the preengineering mockup critical (pre-EMC). Since the pre-EMC core may approach a volume of 4400 liters, the simulated steam ingress experiments will be confined to small, but adequate, zones at core center. Here the objectives will be the effects of steam worth due to (1) variation of plutonium isotopic makeup (use of high Pu-240 fuel), (2) alternative fuel types (U-233, Th), and (3), a uniform poisoning to simulate fission product buildup. Also, studies will be continued with more realistic mockups of GCFR control rods in typical power core arrangements, perhaps with checks on the influence of steam environment. Again, temperature coefficients of worth for samples of the fertile (U or Th) materials will be measured.

In the area of methods development, work will continue toward implementation of the new spectrum/cross section code MICROX-2, Including provisions for more automated handling of output cross section sets. The use of MICROX-2 will greatly facilitate the running of numerous cross section sets, at different temperatures, compositions, etc., which are required to adequately analyze the effects of steam ingress versus density in the GCFR at various stages of burnup, heatup, and control rod configuring.

At this time, there have been no updates to the calculations of worth-versus-density curves for accidental steam entry for the current 300-MW(e) GCFR demonstration plant design. However, a single point value for a previous low $\Delta \mathrm{p}$ core design was calculated with a rigor comparable to the aforementioned critical experiment analysis and also using ENDF/B-4 data. At $0.0075 \mathrm{~g} \mathrm{H}_{2} \mathrm{O} / \mathrm{cm}^{3}$ in the coolant channels, the steam flooding worth for a fresh, unrodded core at operating temperature was calculated at $-\$ 1.85$, similar to the results reported by Torri (Ref. 8) using ENDF/B-3. 
The future physics analyses for the updated reference design of the GCFR demonstration plant will include studies of the impact of steam ingress on reactivity; however, these will be confined to a density range determined from a realistic assessment of potential ingress.

PERSPECTIVE ON THE SAFETY IMPACT OF STEAM INGRESS

There have been many concerns expressed in the past that the steamingress potential presented a safety problem for the GCFR concept. Part of the concern stemmed from uncertainty of the effects, in view of the seemingly wide divergence in sign and magnitude reported by different theoretical investigations using different methods and approximations and different nuclear data bases. Much of the problem arose because of the unrealistically high range of assumed achievable coolant channel watervapor densities. Finally, simulated steam entry experiments in fast reactor criticals pointed to a positive density coefficient of reactivity.

On the last point, it is clear that for conditions in the power reactor core akin to the critical experiment environments, i.e., in a clean (unburned), unrodded, cold situation, the ingress of steam into the core coulatut channels would produce a positive reactivity signal. Such an environment cannot occur since (1) there would be no steam available in the cold condition, and (2) the fuel management scheme and startup procedure with a fresh core require significant poisoning by control. rods in the cold state. Pruceeding to operational temperatures by partial rod withdrawals should assure a negative steam entry worth over any realizable density range just due to the temperature-induced extra neutron absorption in uranium.

In much of the early steam worth analysis, it is not clear what tcmperatures were assuined for the fuel. Also, in many cases the cross section regenerations for different steam densities were nonexistent or inadequate, as assessed by our current understanding of the precautions required for accurate steam reactivity predictions. In some cases, 
simple fundamental mode solutions were employed with the assumption of constant bucklings to represent spatial leakage, even for whole reactor, high density steam floodings. Prescriptions for leakage parameters (diffusion or transport cross sections) can significantly alter steam worth predictions, as discovered in our own upgrading of methods, including the adjustments for streaming of neutrons down the coolant channels.

Improvement in the available nuclear data bases over the past 15 years has caused significant changes in calculated steam worths, especially due to the higher evaluations of plutonium and U-238 capture cross sections. Differences between current updated cross section libraries employed in various countries, and for future evaluations in ENDF/B, doubtlessly also will produce a spread of results approaching $\pm 25 \%$ but should not produce any startling change which would imply a safety problem.

Regarding the limits to the allowable coolant channel steam density, it would be conservative to assume that even for an end-of-cycle core (burned) with all control rods inserted, there will be some level of water vapor density in the coolant at which the total worth of the ingress effect will cross over from negative to positive. However, based on the current experimental evidence and the successfully validated analytical procedures, the crossover point will be well beyond the upper density limits imposed by the engineering constraints, even considering analytical uncertainties.

As a tinal perspective, one can compare a pessimistic assessment of the maximum reactivity ramp possible from steam ingress to that which could result from a control rod withdrawal event. The maximum steaminduced ramp can be derived by combining the experimentally determined reactivity insertion limit with the maximum steam leak. A highly conservative upper bound for the differential worth would be the positive $\$ 0.74 / \%$ steam ( $\mathrm{CH}_{2}$ equivalent) measured in the cold, unrodded, clean Phase II GCFR critical experiment which was fueled with low $\mathrm{Pu}-240$. Considering the large volume of the primary coolant enclosure, a $90 \mathrm{lb} / \mathrm{sec}$ leak (twice the current criteria) would produce a reactivity ramp of 1 ess than $0.4 \mathrm{c} / \mathrm{sec}$. 
This compares with an estimate of $2.5 \mathrm{c} / \mathrm{sec}$ for an uncontrolled withdrawal of the maximum worth rod. Furthermore, the steam generator inventory limit would restrict the maximum steam density to about $0.7 \%$ for a maximum reactivity effect of $\$ 0.52$, compared with $\$ 2.80$ for the rod withdrawal accident.

Figure 8 presents a graphic comparison of the reactivity insertion versus time due to a rod withdrawal accident with the reactivity variations induced by a maximum steam generator leak ( $90 \mathrm{lb} / \mathrm{sec}$ ) under various assumptions. The solid curves in the figure were derived from rod worth and steam worth versus density calculatinns, using validated methods, for a 300-MW(e) GCFR at power, with and without control rods and/or fission product poisoning. The dashed curves are based on the experimental worths of simulated steam flooding found in the small-core GCFR critical experiments, translated into a reactivity ramp using the assumed density buildup versus time as for the plant ingress.

While a variety of conditions are illustrated in Fig. 8, it is obvious that within the range of allowable steam densities, steam ingress will not be a limiting reactivity insertion event for safety consideration in a GCFR. Future analyses on revised demonstration plant designs may alter the calculated steam ingress worth curves, but for all realistic situations, the steam reactivity effect will be below that shown by the measurements in the cold, 1300-1iter core Phase II critical assembly.

\section{REFERENCES}

1. "A Study of a Gas-Cooled Fast Breeder Reactor. Initial Study: Core Design Analysis and System Development Program," USAEC Report GA-5537, Gencral Dynamics, General Atomic Division, 1964.

2. Fortescue, P., et al., "Safety Characteristics of Large Gas-Cooled Fast Power Reactors," Proceedings Conf. on Safety, Fuels, and Cort Design in Large Fast Power Reactors, ANL-7120, Argonne National Laboratory, 1965, p. 230. 
3. Hallam, J. W., et al., "The Flood Safety of Steam and Gas-Cooled Fast Reactors," Proceedings Conf. on Safety, Fuels, and Core Design in Large Fast Power Reactors, ANL-7120, Argonne National Laboratory, 1965, p. 826.

4. "Design Study of a 1000 MW (e) Gas-Cooled Reactor Plant, Vol. 1, Conceptual Design," GA-7240, General Dynamics, General Atomic Division, 1966.

5. "Physics and Safety Analyses, Turbine Drive Penetration and Circulator Feasịbility Studies for a 1000 MW(e) Gas-Cooled Fast Breeder Reactor," GA-8464, Gulf General Atomic, March 1968.

6. Pellaud, Bruno, "The Physics Design of the Gas-Cooled Fast Breeder Reactor Demonstration Plant," USAEC Report GA-10509, Gulf General Atomic, August 29, 1971.

7. Broido, J. H., and M. P. Rothstein, "The Effect of Steam Entry on the Gas-Cooled Fast Breeder Reactor Demonstration Plant," GulfGA-A12041, Gulf General Atomic, May 1972.

8. Torri, A., and M. J. Driscoll, "Reactivity Insertion Mechanisms in the GCFR," GA-A12934, General Atomic Company, April 1974.

9. Kiefhaber, E., and K. Ott, "Survey Parameter Study of Large SteamCooled Fast Power Reactors," Proceedings Conf. on Safety, Fuels, and Core Design in Large Fast Power Reactors, ANL-7120, Argonne National Laboratory, 1965.

10. Jirlow, K., "Reactivity Dependence of Coolant Density in Steam-Cooled Fast Reactors," Paper SM-101/52, Proceedings Symposium on Fast Redilur Physics, Vol. 11, International Atomic Energy Agency, 1968.

11. Kiefhaber, E., "Reactivity Coefficients of Steam-Cooled Fast Breeders," Proceedings Symposium on Fast Reactor Physics, Vol. II, International Atomic Energy Agency, 1968.

12. Stegemann, D., et al., "Physics Investigations of a 670-Litre SteamCooled Fast-Reactor System in SNEAK, Assemb1y 3A-1," Paper SM-101/11, Froceedings Symposium on Fast Reactor Physics, Vol. II, International Atomic Energy Agency, 1968. 
13. Tiren, L. I., et a1., "Studies of the Doppler Coefficient and the Reactivity Effect of Polythene in Some Fast Reactor Spectra," Paper SM-101/3, Proceedings Symposium on Fast Reactor Physics, Vo1. II, International Atomic Energy Agency, 1968.

14. Beck, C. L., et al., "Demonstration Plant Benchmark Central Reactivity Measurements," Paper II-37, Applied Physics Division Annual Report, USAEC Report ANL-7910, Argonne National Laboratory, January 1972.

15. Moore, R. A., "A Critical Experiment Program for the 300-MW(e) GasCooled Fast Breeder Reactor--Scope and Purpose," USAEC Report GulfGA-A12780, General Atomic Company, October 1973.

16. Bhattacharyya, S. K., "An Experimental Study of the Neutronics of the First Gas-Cooled Fast Reactor Benchmark Assembly (GCFR Phase I Assembly)," ERDA Report ANL-76-36, Argonne National Laboratory, December 1976.

17. Bhattacharyya, S. K., "Reactor Physics Studies in the Steam Flooded GCFR Phase II Critical Assembly," DOE Report ANL-78-83, Argonne National Laboratory, August 1978.

18. Hess, A. L., et al., "Analysis of Steam Entry Experiments in the Phase I GCFR Critical Assembly," DOE Report GA-A14798, General Atomic Company, March 1978.

19. Hess, A. L., and R. A. Rucker, "Analysis of Fu11 Core Steaming Flooding Experiments for the Phase II GCFR Critical Assembly." 


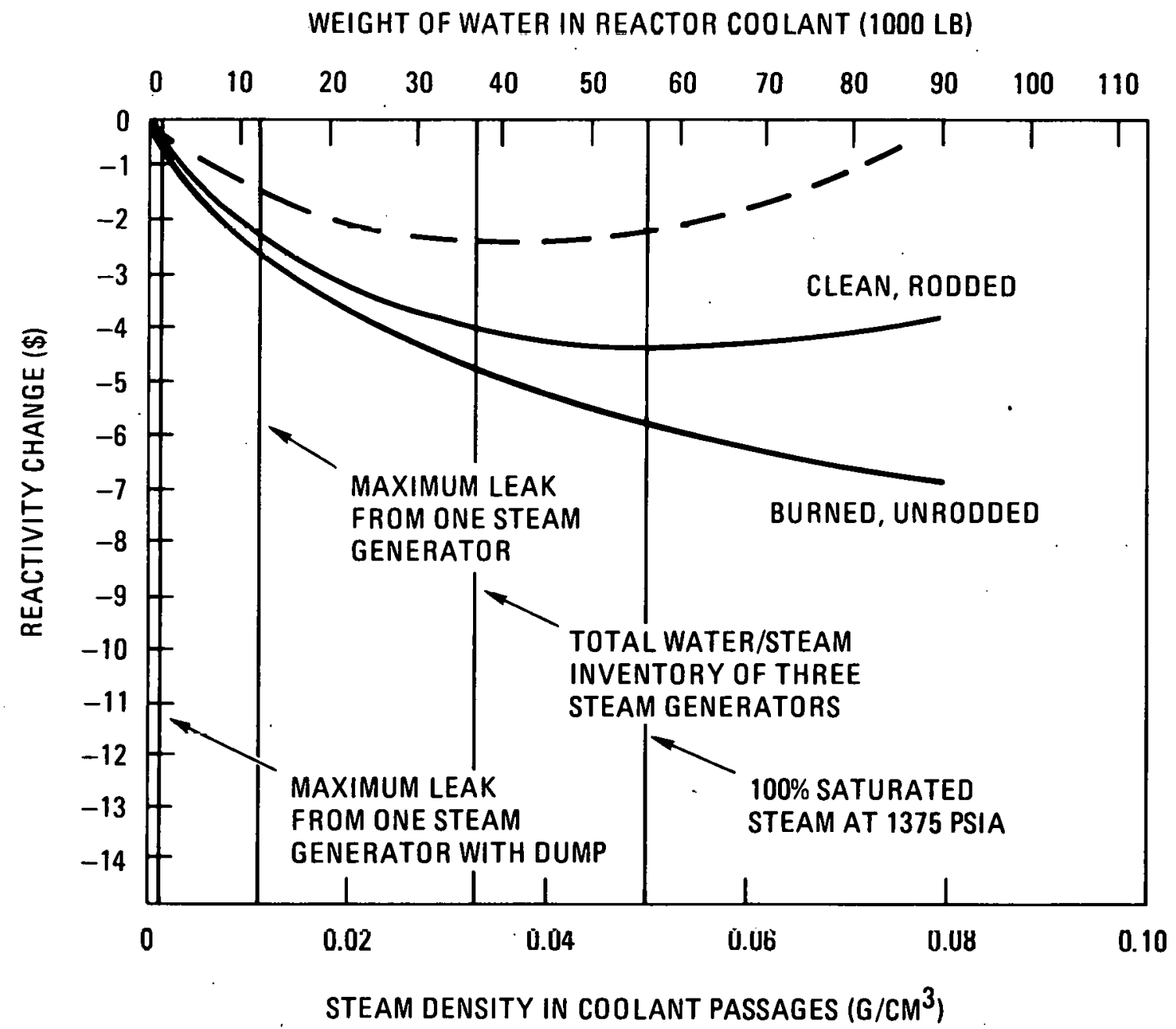

Fig. 1. Reactivity effect of steam entry to GCFR demonstration plant reactor at operating temperature 


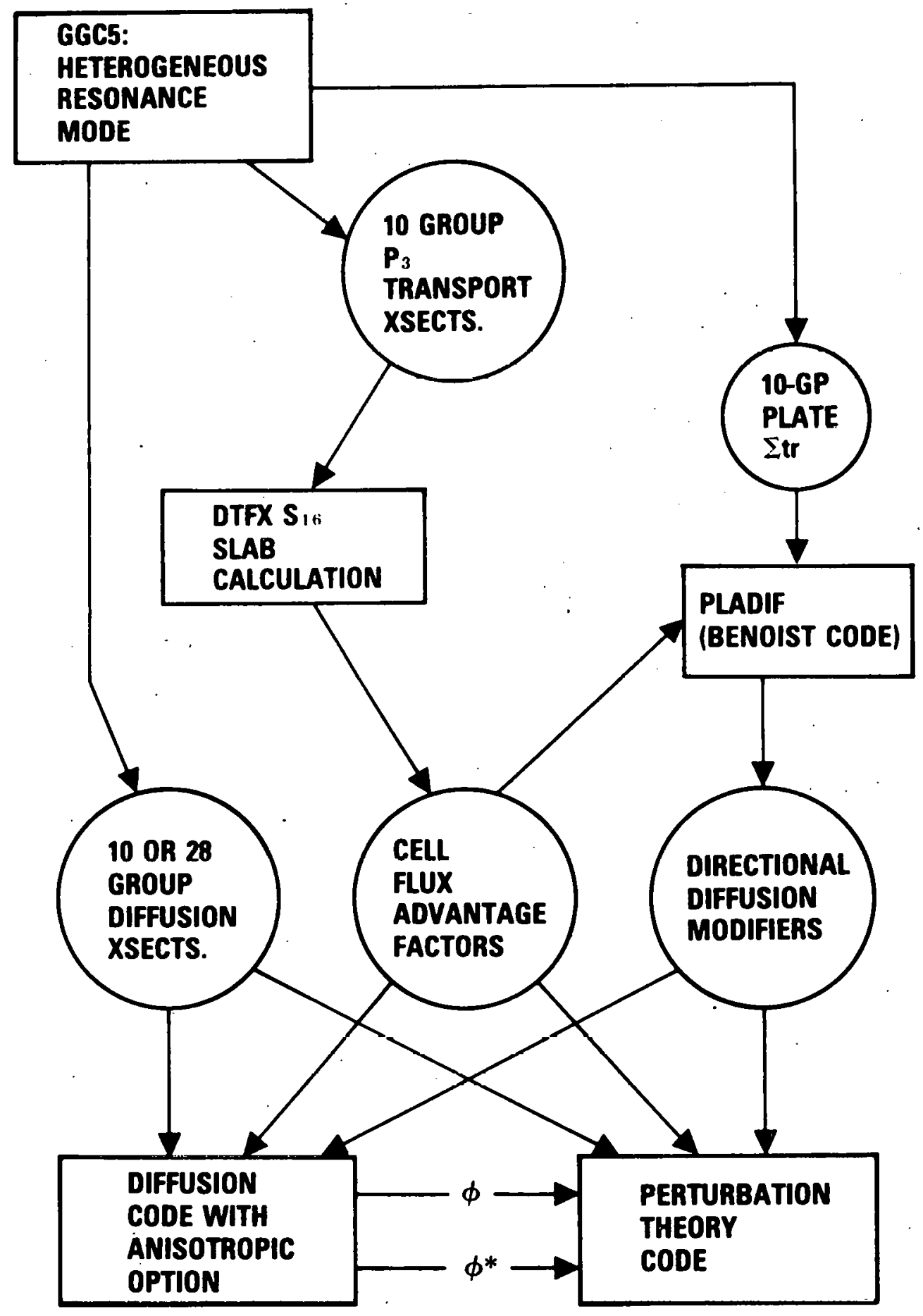

Fig. 2. Steam-worth analysis chart 


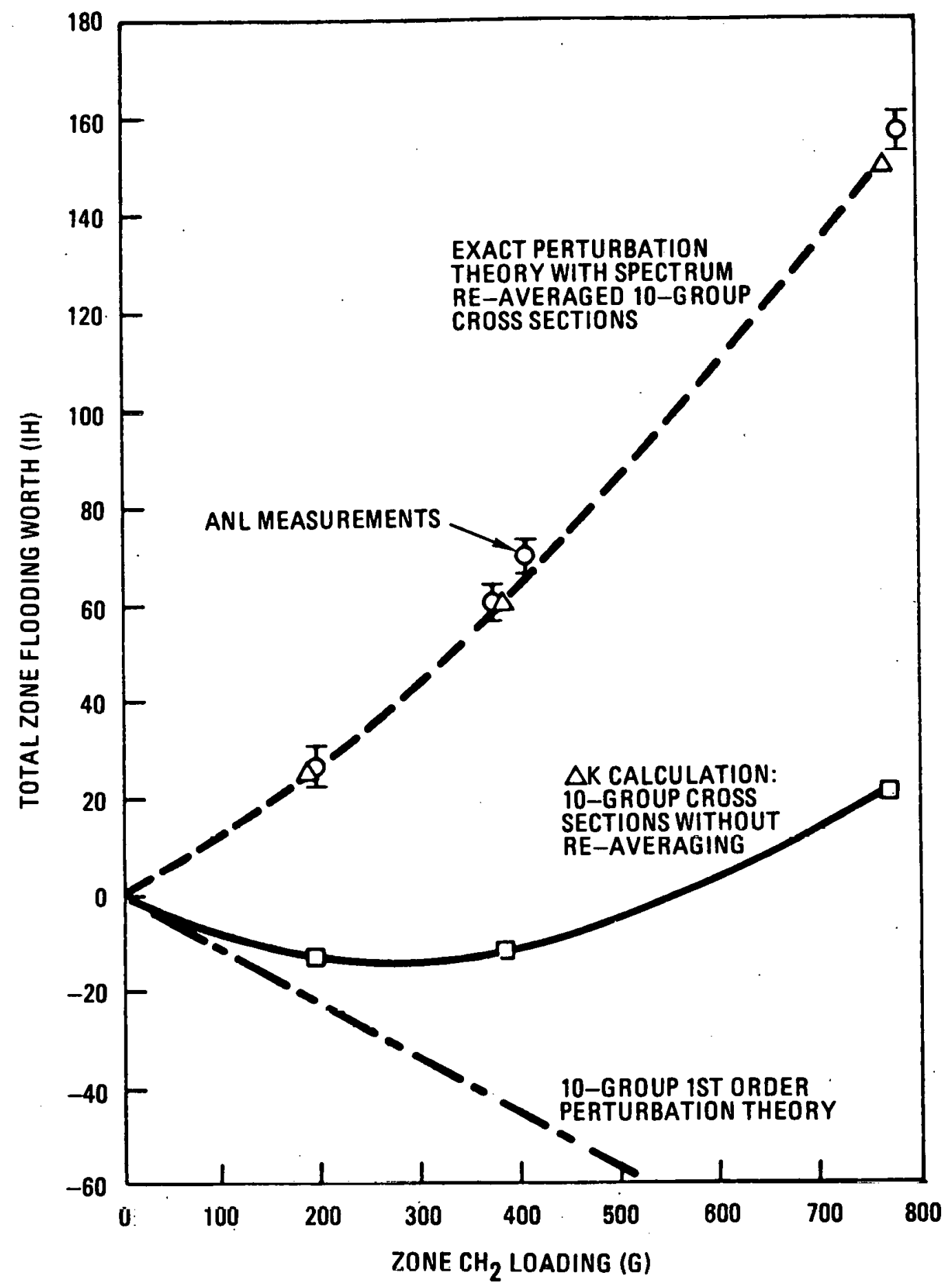

Fig. 3. Measured and calculated worths of simulated steam flooding in central zone of Phase I GCFR assembly 


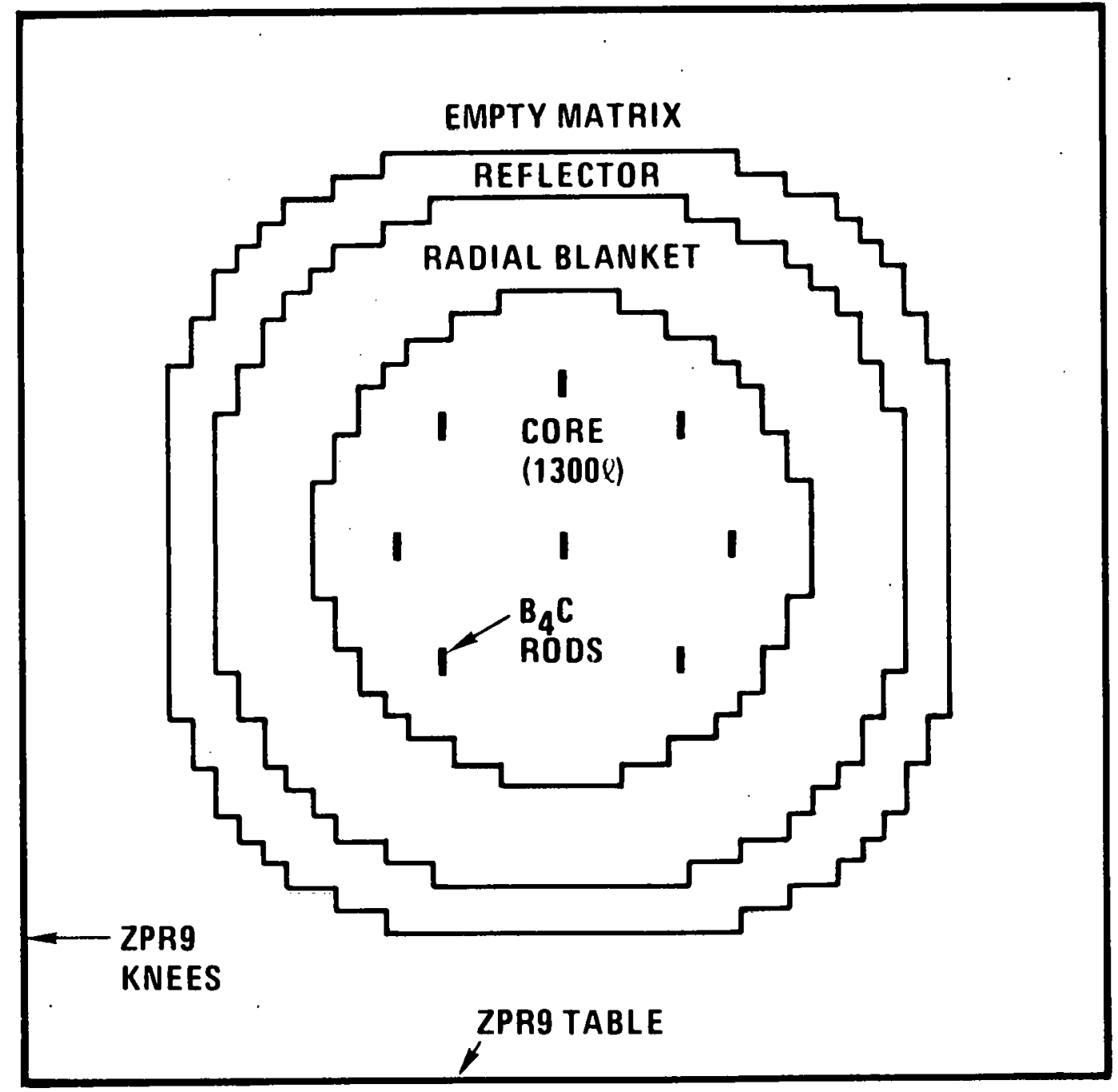

Fig. 4. Midplane view of Phase II GCFR critlcal assembly during steam worth: experiments 


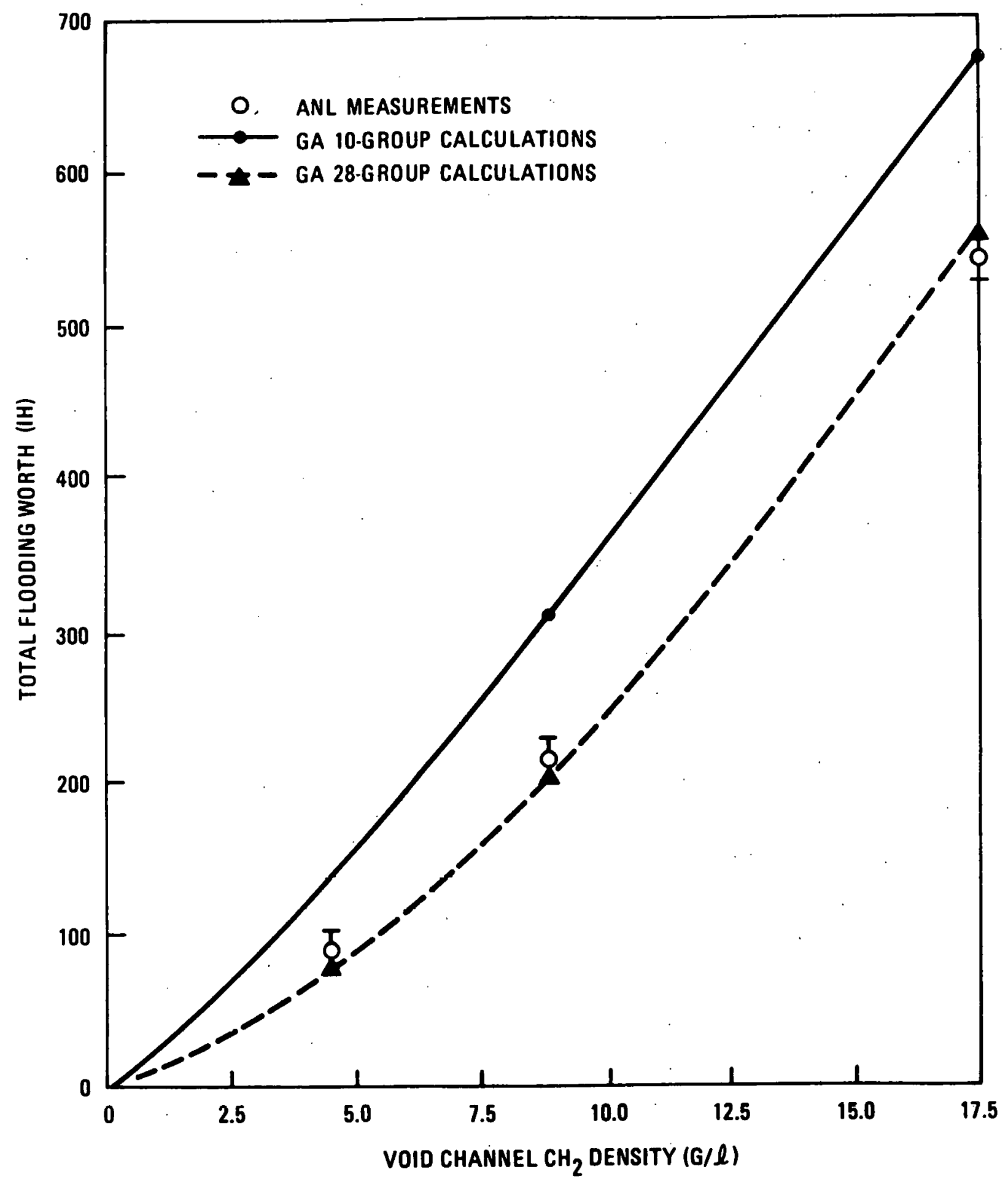

Fig. 5. Worth of simulated steam flooding in unrodded Phase II GCFR assembly with 1150-liter core 


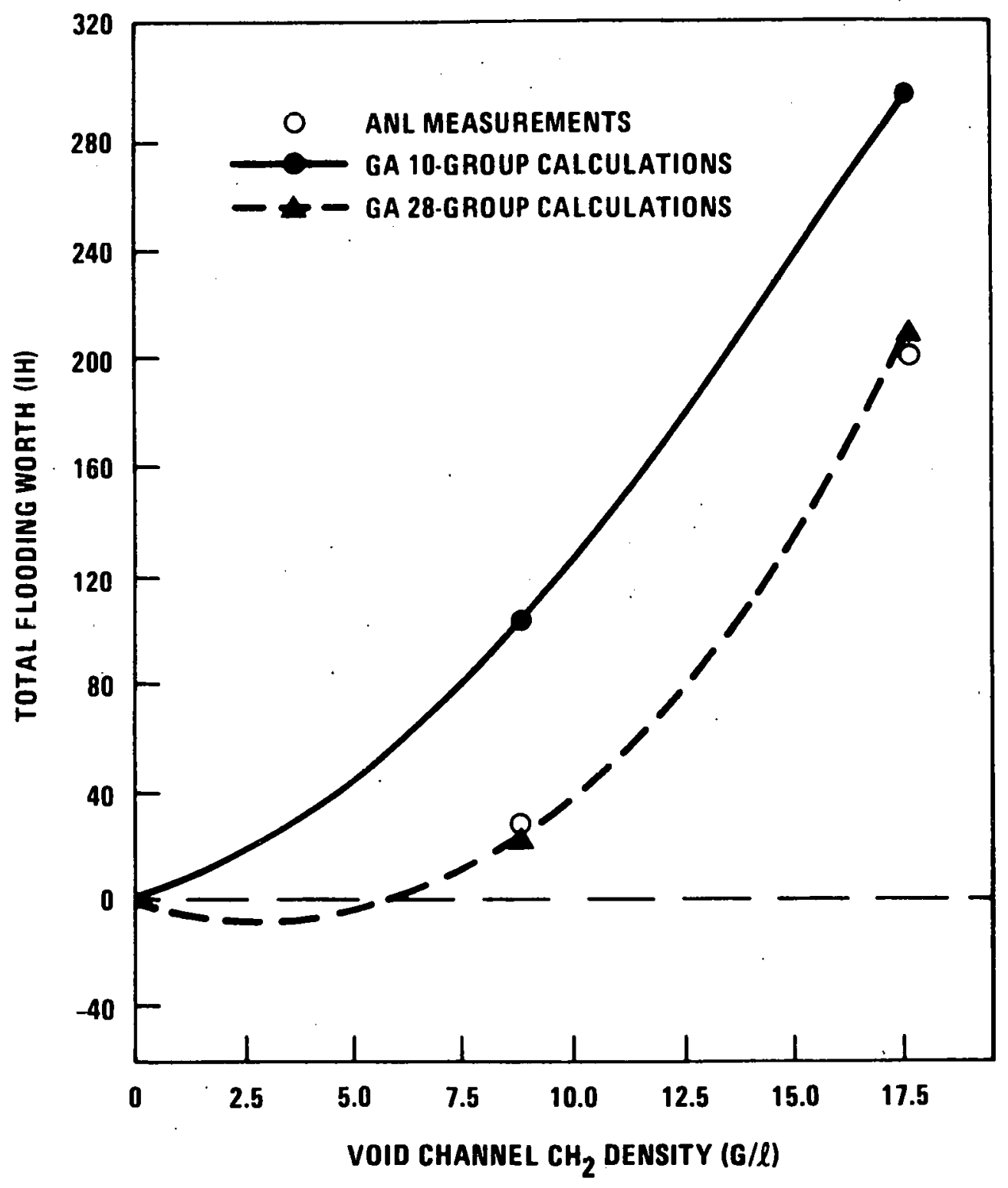

Fig. 6. Worth of simulated steam flooding in Phase GCFR assembly with eight $\mathrm{B}_{4} \mathrm{C}$ rods in a $1350-1$ iter core 


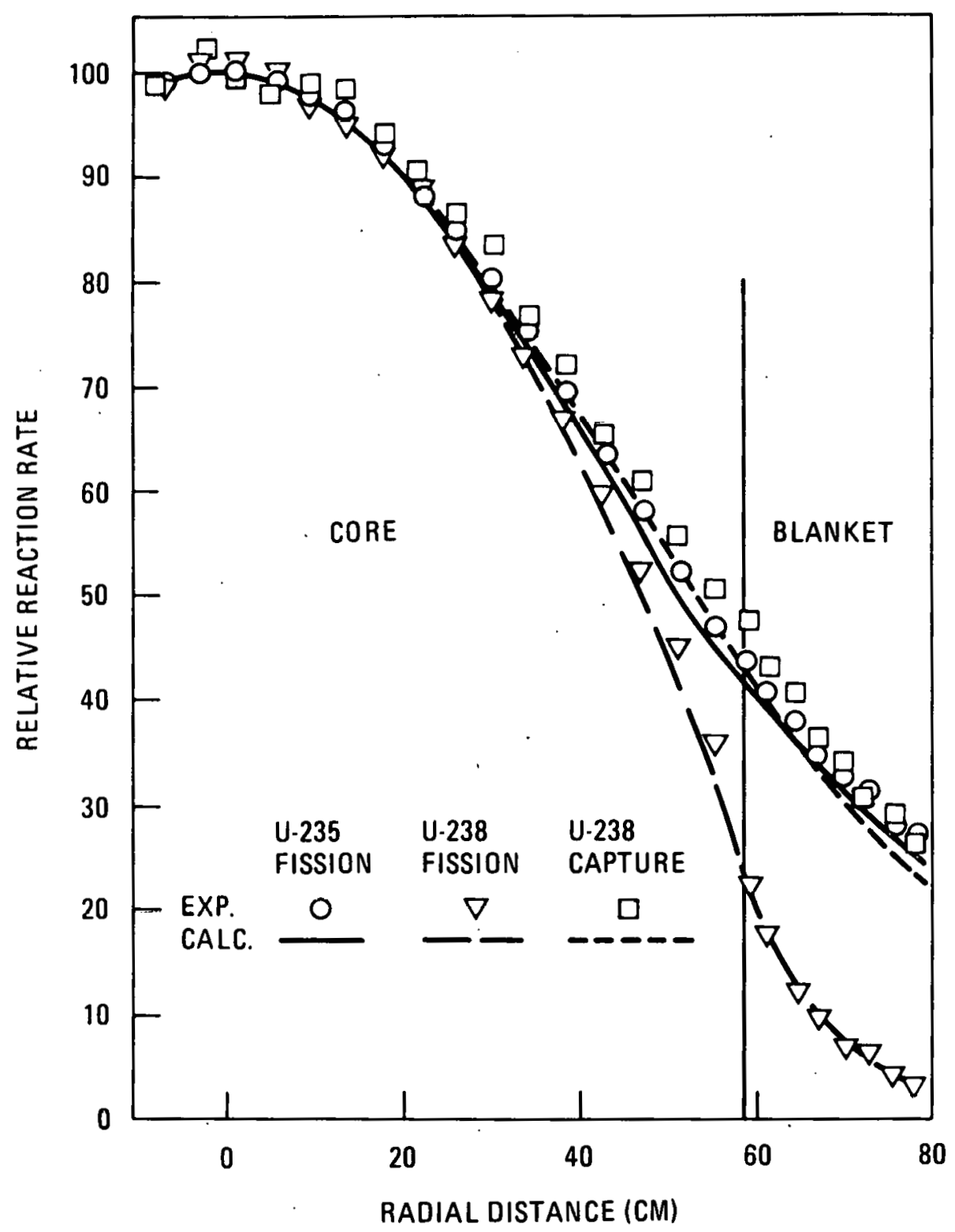

Fig. 7. Radial reaction rates for GCFR Phase II reflector assembly 


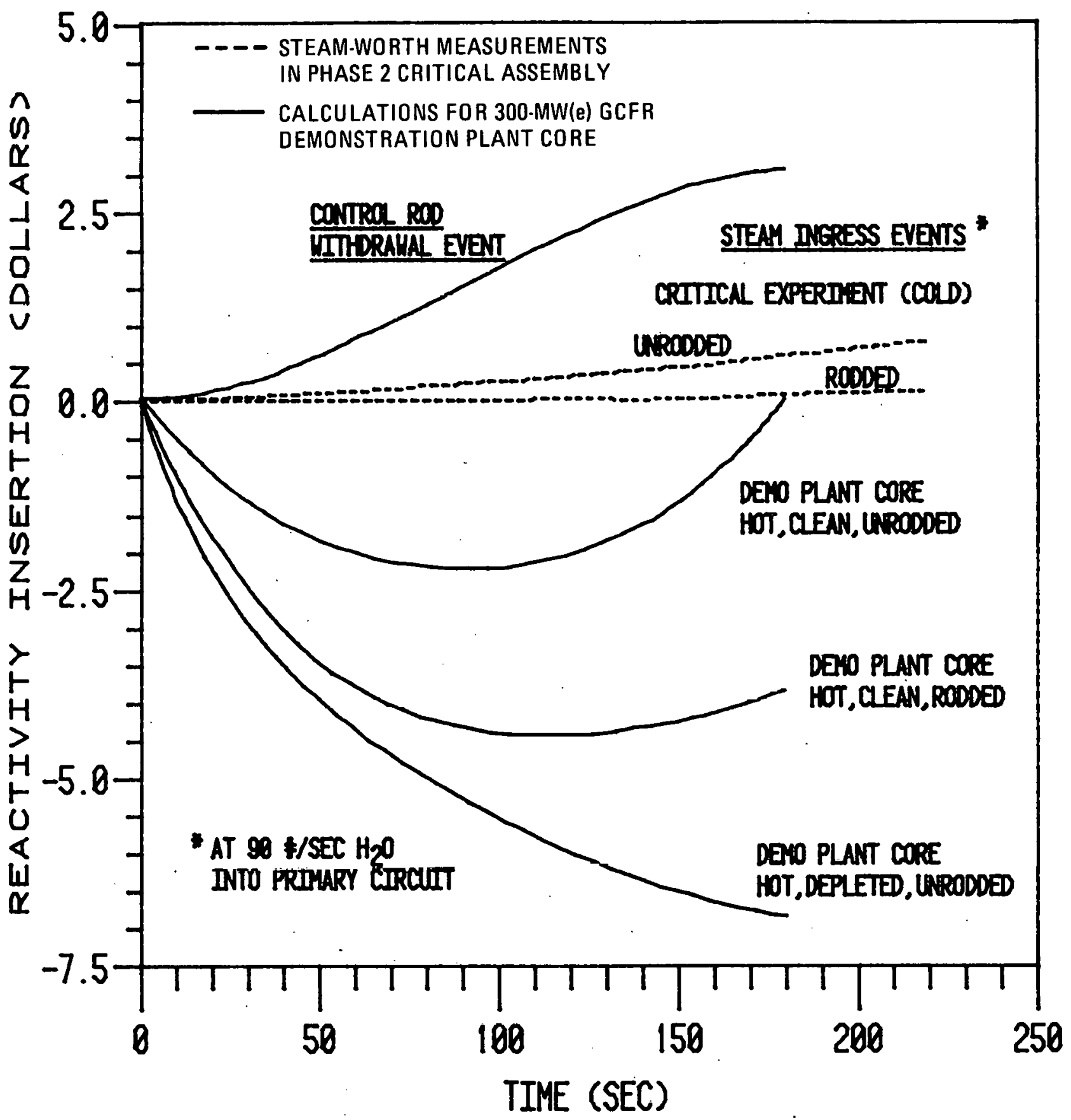

Fig. 8. Comparison of reactivity insertion rates from hypothesized steam ingress events and a rod withdrawal event in a GCFR core 